UDC: $336.055(497.16)$

UDC: $336.055(497.11: 492)$

DOI: $10.1515 /$ jcbtp-2015-0005

Journal of Central Banking Theory and Practice, 2015, 1, pp. 63-93

Received: 23 October 2014; accepted: 11 November 2014

Milena Vučinić *

\section{Financial Stability - Comparative Analysis: Montenegro, Serbia and the Netherlands}

\begin{abstract}
The global financial crisis has had far-reaching effects on financial systems and economies all over the world, thus putting the importance of safeguarding financial stability in the focus of interest of the global economy.
\end{abstract}

This paper presents the importance of safeguarding financial stability and building a strong financial system with developed early identification and successful management of risks, i.e. a system resilient to shocks and capable of overcoming them.

The paper focus is on the issue of financial stability of Montenegro, given through comparative analysis of the financial stability safeguarding frameworks in the Netherlands and the Republic of Serbia. The paper aims to present the regulatory institutional framework for safeguarding financial stability, and the measures that the countries take in order to achieve stability of their macroeconomic environment and financial system. The comparison of the characteristics and the approach to safeguarding the banking sector is particularly emphasised due to its major influence on the financial system stability.

Key words: financial system, financial (in)stability, macroeconomic stability, fiscal consolidation measures, risk management

JEL code: E52, E58, E62
${ }^{*}$ Central Bank of Montenegro

E-mail:

milena.vucinic@cbcg.me 


\section{Introduction}

The recent financial crisis shifted the focus of the global economy to the importance of safeguarding financial stability. Until recently, the maintenance of price stability was regarded as the fundamental and most important factor in securing a stable financial and economic growth. However, the global financial crisis showed how strong the effects of the destabilisation of the financial system could be, i.e. to what extent they could threaten the sustainability of the economic system as a whole and lead to a crisis of global proportions. Thus, the crisis pointed to the necessity of safeguarding of the financial system.

Although price stability is still treated as a priority objective in the majority of central banks, numerous international financial institutions have recognised financial stability as one of the key objectives. Financial stability is nowadays deemed more and more an issue of public interest, therefore it is necessary that the institutions responsible for safeguarding financial stability in every country recognise its fundamental importance and contribute to its preservation.

There have been numerous consequences of the global financial crisis which stemmed from the collapse of the global financial market: economic growth deceleration, drastic increase of unemployment worldwide, population dissatisfaction, decrease in consumption, increase in public debt and fiscal deficit, decline in bank lending, and high levels of nonperforming loans. Some countries experienced riots induced by poor economic and financial situation. In order to make these circumstances a part of the past, it is of essence to create a sound system capable of responding to problems and resilient sudden adverse events.

There are several reasons affecting this particular choice of countries to be compared with Montenegro. Serbia is a neighbouring county, and its economy is developing in an environment similar to that of Montenegro, however with some major differences, one of them being the use of its own currency - the dinar. Unlike Serbia, Montenegro uses the euro. The Netherlands is a member country of the European Union as well as the euro area, while in the International Monetary Fund, the Dutch Constituency represents interests of Montenegro ${ }^{1}$. The use of the euro as a legal tender is common to the Netherlands and Montenegro with the distinction that the first is a euro area member while the latter is a non-euro area member.

\footnotetext{
Montenegro is a member of the Dutch Constituency, which also represents interests of 14 more countries, namely: the Netherlands, Belgium, Luxembourg, Armenia, Bosnia and Herzegovina, Croatia, Israel, Macedonia, Bulgaria, Cyprus, Georgia, Moldova, Romania and Ukraine.
} 
Research of the manner in which each of the observed three countries is dealing with the aftermath of the recent financial crisis and striving to maintain financial stability shows that, regardless of their differences, these countries share a great deal of problems. Montenegro, the Netherlands and Serbia differ in population, territory, and economic strength, but that does not necessarily imply that the problems they are facing differ so much.

\section{Financial Stability Definition}

There is no unique definition of financial stability. There have been many attempts to define financial stability. Definitions of financial stability can be more or less divided in two groups. On one side there are experts and institutions that define financial stability while others define its opposite - financial instability.

Garry J. Schinasi (2005) explains: "Financial stability as the situation in which the financial system is capable of satisfactory performing its three key functions: (1) financial system efficiently and smoothly facilitating the allocation of resources from savers to investors and the allocation of economic resources in general; (2) forward looking risk are being assessed and priced reasonably accurately and relatively well managed; and (3) financial system is in such condition that it can comfortably absorb financial and real economic shocks.

All these functions must function simultaneously. Otherwise, the financial system is moving toward other direction - instability."

Roger W. Ferguson, Jr (2002, p.2) defines financial instability as : “...a situation characterized by these three criteria: (1) some important set of financial asset prices seem to have diverged sharply from fundamentals; (2) market functioning and credit availability, domestically and probably internationally, have been significantly distorted, with the result that (3) the aggregate spending deviates significantly, either above or below, from the economy's ability to produce."

Frederick Mishkin (1999, p. 6) defines financial instability and focuses on effects of asymmetric information. According to Mishkin: “... financial instability occurs when shocks to the financial system interfere with information flows so that the financial system can no longer do its job of channelling funds to those with productive investment opportunities. If the financial instability is severe enough it can lead to almost complete breakdown in the functioning of financial markets, to the situation which is classified as a financial crisis." 
The European Central Bank (ECB) defines financial system as: “...a situation in which the financial system can withstand shocks without major disruption in financial intermediation and in the effective allocation of savings to productive investment...The safeguarding of financial stability requires identifying the main sources of risks and vulnerability such as inefficiencies in the allocation of financial resources from savers to investors and the mismanagement of financial risks... This identification of risks and vulnerabilities is necessary because the monitoring of financial stability must be forward looking; inefficiencies in capital allocation and risk management can lay the foundations for vulnerabilities and compromise future financial stability and economic stability." ${ }^{2}$

\section{Comparative analysis of financial stability on the examples of Montenegro, Serbia, and the Netherlands}

Experience has shown that financial crises usually originated from the banking crisis. In order to reach the key comparison, i.e. the situation in the banking system of all three countries, the context and/or general and macroeconomic characteristics of the countries shall be presented first.

\subsection{Comparative analysis - general characteristics}

\subsubsection{Country status vis-à-vis the EU}

The Netherlands is a member of the European Union, while Serbia and Montenegro have the status of candidate countries. The Netherlands is a member of the euro area while Serbia and Montenegro are not, with the distinction that Montenegro uses the euro and Serbia has its national currency, the dinar.

\subsubsection{The role of the central bank in maintaining financial stability}

Pursuant to Article 143 of the Constitution of Montenegro and Article 4 of the Central Bank of Montenegro Law, the main objective of the Central Bank shall be to foster and maintain financial system stability. The Central Bank of Montenegro (CBCG) is the regulator of the banking system and, in accordance with that function, it adopts secondary legislation and initiates the adoption of laws governing the banking industry.

\footnotetext{
2 http://www.ecb.europa.eu/pub/fsr/html/index.en.html
} 
With the use of euro, the Central Bank does not have the issuing function. Pursuant to Article 5 of the CBCG Law, the Central Bank shall have the exclusive right to issue banknotes and coins in the event Montenegro decides to introduce a national currency.

De Nederlandsche Bank (DNB) operates as an independent institution. DNB has the primary objective same as that of the EU - maintaining price stability, which is defined as inflation below, but close to $2 \%$. DNB operates as an independent central bank and supervisor to ensure price stability and balanced macroeconomic development in Europe, together with the other central banks of the Eurosystem, a shock-resilient financial system, and a secure, reliable and efficient payment system and strong and sound financial institutions that meet their obligations ${ }^{3}$. The promotion of financial stability has been enshrined in the Bank Act as a DNB task from January 2014. DNB has been given macroprudential instruments to fulfil this task. The first of these instruments to be deployed by $\mathrm{DNB}$ is the imposition of an additional capital buffer requirement for the four systemically important Dutch banks: ING Bank, Rabobank, ABN AMRO, and SNS Bank. Fulfilling all these buffer requirements will increase their resilience to potential shocks (DNB, 2014a).

The primary objective of the National Bank of Serbia (NBS) is to achieve and maintain price stability, while its key role is to secure monetary and financial stability. Therefore, without prejudice to its primary objective, the NBS also contributes to the maintaining and strengthening of financial stability. Serbia uses dinar as its national currency, therefore the instruments it can use in pursuing monetary policy are numerous. ${ }^{4}$

\subsubsection{Central bank as the supervisory authority}

In all three countries, the banking sector supervision is performed by the respective central banks. As for the non-banking sector, the CBCG performs the supervision of microcredit financial institutions as well. In addition to the banking sector, DNB controls the operation of insurance companies and pension funds, while the NBS performs the supervision of insurance companies, pension funds and financial leasing.

3 http://www.dnb.nl/en/about-dnb/onze-missie/index.jsp

${ }^{4}$ http://www.nbs.rs/internet/cirilica/30/index.html and http://www.nbs.rs/internet/cirilica/10/index.html 


\subsubsection{Credit rating}

In November 2014, a rating agency Standard \& Poor's published its report on Montenegro in which it lowered its previous rating from "BB-" to "B+". Montenegro was confirmed the stable outlook, which indicates that the further rating trends are based on stable positions. However, rating agency Moody's confirmed its "Ba3" rating in October 2014, but changed the outlook from stable to negative (Table1).

In April 2014, Standard \& Poor's confirmed Serbia's "BB-" credit rating but with negative outlook, while, Moody's assigned Serbia with B1 rating and stable outlook in July 2013 (Table 1).

In November 2013, Standard \& Poor's lowered credit rating assigned to the Netherlands from "AAA" to "AA+", while Moody's confirmed its "Aaa" rating, changing its outlook from negative to stable (Table1).

Table 1: Credit rating assigned by Standard and Poor's and Moody's

\begin{tabular}{|c|c|c|c|}
\hline \multicolumn{4}{|c|}{ Credit rating } \\
\hline & Montenegro & Serbia & Netherlands \\
\hline $\begin{array}{l}\text { Standard and } \\
\text { Poor's }\end{array}$ & $\begin{array}{l}\text { Rating lowered from BB- to } \\
\text { B+ but with confirmed stable } \\
\text { outlook } \\
\text { (November 2014) }\end{array}$ & $\begin{array}{l}\text { BB-; } \\
\text { Confirmed rating, but } \\
\text { with negative outlook } \\
\text { (April 2014) }\end{array}$ & $\begin{array}{l}\text { Rating lowered from AAA } \\
\text { to AA+ } \\
\text { (November 2013) }\end{array}$ \\
\hline Moody's & $\begin{array}{l}\text { Confirmed Ba3 rating, but } \\
\text { outlook changed from stable } \\
\text { to negative (October 2014) }\end{array}$ & $\begin{array}{l}\text { Assigned B12 rating } \\
\text { with stable outlook } \\
\text { (July 2013) }\end{array}$ & $\begin{array}{l}\text { Confirmed Aaa rating, } \\
\text { outlook changed from } \\
\text { negative to stable } \\
\text { (March 2014) }\end{array}$ \\
\hline
\end{tabular}

Source: Author's table based on data of relevant institutions of the selected countries

\subsection{Safeguarding financial stability - Comparative analysis}

\subsubsection{Safeguarding financial stability in Montenegro}

Montenegro's economy is small, open and highly exposed to the effect of international economic trends, therefore it could not stay immune to economic crisis impact. Montenegro has emerged from recession, but the recovery remains slow and very challenging. One should bear in mind that, after the restoration of the country's independence, the Montenegrin economy was recording high growth rates; however, after the global crisis outburst, those rates plummeted. 
With a view to safeguarding financial stability, Montenegro has been working on developing an approach to financial stability that implies the obligation of monetary and economic policymakers to continuously monitor, analyse and act appropriately in order to prevent any occurrence that could jeopardize financial and economic stability.

With a view to monitoring, identifying, preventing and mitigating potential systemic risks in the financial system of Montenegro as a whole, as well as ensuring the safeguarding of the financial system stability and avoid influences of negative factors, Montenegro established the Financial Stability Council. The Council was established under the Financial Stability Council Law (Official Gazette of Montenegro 44/10 as of 30 July 2010). The members of the Council are the Governor of the Central Bank, the Minister of Finance, the Chairman of the Security and Exchange Commission, and the Chairman of the Insurance Supervision Agency Council.

Measures of fiscal consolidation in Montenegro - The financial crisis has had a significant impact on Montenegro's financial system. Liquidity of the financial sector and the real economy were jeopardized. The Government took up fiscal consolidation measures and in that view adopted a very elaborate anti-crisis package, followed by a string of other measures directed towards public finances stabilisation which, inter alia, understood the control and reduction of spending, austerity in discretionary spending, and suspending new employment. The efficiency of fiscal consolidation measures became apparent already in the first years of implementation in the period 2008 - 2010, when spending recorded a decline of an approximate 9 percentage points of GDP. The implementation of fiscal policy measures continued in the following years, and in early 2013 they were intensified through the introduction of a set of urgent measures. The measures are aimed at stopping further growth of the fiscal deficit and the public debt, and improving revenues collection. Measures implemented in view of reducing the expenditure side are the following: reduction of operating expenses for the operations of committees and task forces, pension adjustment freeze, reduction of costs in public companies, regulatory agencies, and local self-governments. The measures on the revenue side of the budget were: the introduction of the crisis tax which modified the manner of taxation of personal income (gross wages exceeding 720 euros are levied by additional 6\%, i.e. at the tax rate of 15\%); the minimum wage was increased from $30 \%$ to $40 \%$ of an average wage; the VAT rate was increased from $17 \%$ to $19 \%$; efforts were put in combating shadow economy; excise duties for tobacco products were harmonised; excess incomes of the regulatory agencies was transferred to the budget, and activities were conducted with the aim of reducing tax debt (MF, 2013a). 
Measures of fiscal consolidation contributed to the creation of positive trends regardless of the calling of guarantees provided for the Aluminium plant in the amount of 103.1 million euros in 2013 (MF, 2013b). In line with the principles of fiscal consolidation, the level of public debt can increase only if it is in the function of economic growth. This means that the government may borrow only for the purpose of financing development and infrastructure projects. In their Guidelines for macroeconomic and fiscal policy for the period 2014-2017, the Ministry of Finance stated that the further implementation of measures of fiscal consolidation of the current budget is expected to have an adverse effect on aggregate spending. The Ministry also stated that the construction of the Smokovac - Mateševo highway section, which is planned to be realised through the capital budget of 809.0 million euros over the period of four years should positively influence the increase of demand and total economic activity (MF, 2014b).

Lack of liquidity in of the corporate sector and the high level of nonperforming loans still pose risks for the financial stability. The issue of a high share of nonperforming loans in total loans in Montenegro's banking system, pointed to the necessity of taking measures to address this issue. With a view to reducing the amount of nonperforming loans, a systemic initiative was created by the experts from the World Bank, the Central Bank of Montenegro, and the Montenegrin Ministry of Finance called Podgorica Approach. The project addresses the issue of creditordebtor relations through voluntary financial restructuring. The aim is to reduce the level of nonperforming loans which have an adverse effect on financial stability and economic growth. The model is based on the standards and best solutions in the area of voluntary out-of court restructuring of debts applied in the international practice and adjusted to local conditions and turned into the new Law on Voluntary Financial Restructuring. The law has a lex specialis status and it determines the conditions and manner of voluntary restructuring of debt in financial institutions (banks and microcredit financial institutions licensed by the Central Bank of Montenegro), and companies seated in Montenegro which perform lease operations. The restructuring covers legal persons, including entrepreneurs, and private users of mortgage loans. The model may be applied only to debtors eligible for financial restructuring, meaning that they are experiencing financial difficulties but which are going concerns. Loans classified as " $\mathrm{B}$ " and "C" (over 30 days to maximum 270 days past due) are also included. One of the basic principles this project is based upon is the principle of voluntarism, meaning that the financial restructuring is conducted voluntarily, based on the agreement between creditors and debtors. Financial restructuring may be conducted only if the debtor and at least one financial institution acting as creditor agree to take part in this process. In addition to financial institutions, all other domestic and foreign creditors, including foreign banks may take part in financial restructuring (CBCG). 


\subsubsection{Safeguarding financial stability in the Netherlands}

Regardless of being a highly advanced EU country, the Netherlands has experienced severe effects of the economic crisis. The crisis showed that advanced countries are not immune to financial market disturbances. De Nederlandsche Bank regards the increase of competitiveness and economic growth, as well as creating adequate economic flexibility and resilience to shock, to be the best way to avoid imbalances in the economy (DNB, 2013c). The Netherlands has a very strong competitive position. The share of educated work force is of particular importance, as are the well-developed infrastructure, developed pension funds, and high credit rating. Regardless of these positive features, the consequences of the global crisis can still be felt, which is illustrated by the decline in economic activity of $0.7 \%$ and $0.8 \%$ in 2012 and 2013, respectively (DNB, 2013a). Finally, the Dutch economy showed mild signs of growth in 2014. Economic growth for 2014 is estimated to $0.2 \%$ (DNB, 2014a).

In 2012, the Netherlands established the Financial Stability Committee in the aim of strengthening the cooperation between the institutions which contribute to the preservation of financial stability. The Committee is chaired by the President of De Nederlandsche Bank, and the members of the Council are the representatives of the Ministry of Finance, Authority for Financial Markets and De Nederlandsche Bank (DNB, 2013a).

The Netherlands, as a euro area member, puts a strong focus on the application of initiatives conducted with the aim of preservation of the euro as a currency, and strengthening of the single and stable financial market. In order to overcome the aftermath of the economic crisis, the Dutch government and De Nederlandsche Bank established bodies and mechanisms on the national level, while as a member of the EU and the euro area, it takes part in the creation and implementation of a broad spectrum of mechanisms established at that level. In that context, one of the most important projects is the establishment of the European banking union, on which the EU has been intensively working, in order to create a single regulatory framework, single supervision of the banking sector, and a uniform approach to NPL resolution.

The main purpose of the banking union is to bring an end to the negative interaction between governments and banks. There are three pillars of banking union: Single Supervisory Mechanism (SSM), Single Resolution Mechanism (SRM) and European Deposit Guarantee Scheme. According to SSM European Central Bank will be responsible for banking supervision for the entire euro area. Common banking supervision is significant reform. The implementation of SRM will begin 
from January 1, 2015. All member states are supposed to create national resolution authorities, while there will be the Central European resolution mechanism. DNB will be the national resolution authority in the Netherlands (DNB, 2014b).

Fiscal consolidation measures in the Netherlands - In order to deal with the consequences of the global economic crisis in an efficient manner, the Dutch government, in cooperation with the competent institutions, implemented extensive fiscal consolidation measures. One of the measures was the increase of VAT from $19 \%$ to $21 \%$, as at 1 October 2012 (DNB, 2013b). Consolidation measures aimed at lowering the fiscal deficit below $3 \%$ of GDP. This was effective, and the budget deficit was lowered below 3\%, reaching 2.5\% of GDP at the end of 2013, with the estimates indicating that it shall remain below 3\% at the end of 2014 as well. The implementation of the fiscal consolidation measures, including the reduction of spending and an increase of taxes over the period 2014-2017 is planned to continue. Regardless of the adverse effects entailing the implementation of fiscal consolidation measures, without them, the consequences would be far worse, possibly questioning the sustainability of the public finances. It is approximated that total measures taken in the period 2012 - 2014 amounted to around 5\% of GDP or 34 billion euros, while by 2017 they are estimated to reach more than 50 billion or around $8 \%$ of GDP. Health care system reform and the freezing of public salaries were some of the measures taken on the expenditure side in 2014 (Government of the Netherlands, 2014).

\subsubsection{Safeguarding financial stability in Serbia}

The global financial crisis has left severe consequences to Serbia's economy and its financial system, pointing to the necessity of greater commitment to safeguarding financial stability. The National Bank of Serbia and the Serbian government are working on the establishment of bodies and harmonisation of domestic with international regulations with the aim of dealing with the effects of the crisis and strengthening the resilience of the financial system. Being an EU candidate country, Serbia is working on the harmonisation of its legislation with the Acquis Communautaire. In 2013, the Serbian government, the National Bank of Serbia, the Deposit Insurance Agency, and the Securities and Exchange Commission established the Financial Stability Committee with a view to promoting and strengthening cooperation among the abovementioned institutions in the area of safeguarding financial stability. ${ }^{5}$

\footnotetext{
${ }^{5}$ http://www.nbs.rs/internet/english/scripts/showContent.html?id=6930\&konverzija=yes
} 
Serbia is a signatory to the Vienna Initiative, which helped the country in dealing with the effects of the recent crisis. The Vienna Initiative was established in January 2009 as a response to the financial crisis. To wit, due to the major problems in the financial market, it became increasingly uncertain whether Western European banks with local subsidiaries in the emerging markets of Central, East and South European countries would decide to withdraw from these developing markets. Considering the systemic importance of these banks, their withdrawal from these markets would have exacerbated the already deep systemic crisis. For this reason, at the proposal of the European Bank for Reconstruction and Development, the key international financial institutions (IFIs) agreed to set up an international framework for coordination and cooperation in crisis management - the Vienna Initiative. ${ }^{6}$

With the aim of resolving the issue of nonperforming loans, the National Bank of Serbia composed a Belgrade Initiative draft framework for resolving the issue of NPLs. The framework offers: drafting plans to reduce the share of NPLs, regulating the mandatory write-off of NPLs, continuation of implementing the Law on Consensual Financial Restructuring of Companies, enhancement of the process of out-of-court foreclosure of mortgaged property to improve the process of mortgage enforcement, the establishing of regulatory framework for personal bankruptcy which would improve the resolution of NPLs extended to natural persons (NBS, 2014a).

Measures for dealing with the consequences of the crisis in Serbia - In line with the Law on the Budget System, and in the aim of tackling the issue of high budget deficit and public debt, in 2010, the Fiscal Council and fiscal rules were established in Serbia. The objective of specific fiscal rules is to change the public expenditure structure through the reduction of current expenditure and through a greater scale of public investments. General fiscal rules set the medium-term annual fiscal deficit target at 1\% of GDP. The other fiscal rule stipulates that the general government debt, excluding the liabilities for restitution, shall not exceed $45 \%$ of GDP. The increase in revenues is recorded partially through the harmonisation of salaries and pensions. These rules set the percentage increase of individual salaries in the public sector and pensions. The percentage increase is to be adjusted every April and October up to 2015, until the pension and salary share in GDP reach $10 \%$ and $8 \%$ respectively. In 2012, value added tax was increased from $18 \%$ to $20 \%$. $^{7}$

\footnotetext{
${ }^{6}$ http://www.nbs.rs/internet/english/18/18_8/becka_inicijativa.html

7 http://fiskalnisavet.rs/en/fiscalrules
} 
Serbia's Fiscal Strategy for 2014 plans a reduction of the fiscal deficit to the level of $2.3 \%$ of GDP in 2016. To achieve reductions on the expenditures side of the budget, the Strategy envisages limiting the issuance of guarantees and entering into new project credit arrangements for public companies, in case that the previously granted loans were not efficiently used. In line with the Strategy, the level of public debt is supposed to be reduced to $45 \%$ of GDP by 2025 , which is the threshold determined by the fiscal rules (Government of the Republic of Serbia, 2013).

\subsection{Comparative analysis - Macroeconomic environment}

Studying financial stability requires an overview of macroeconomic factors. Therefore, it is necessary to consider the trending of gross domestic product, inflation, fiscal deficit, public debt, unemployment, and other relevant parameters. Tables 2, 3, and 4 present the most important macroeconomic parameters in the three countries separately, while Table 5 gives the comparison of data.

Table 2: Key macroeconomic indicators in Montenegro

\begin{tabular}{|c|c|c|c|c|c|c|c|c|c|}
\hline & 2007 & 2008 & 2009 & 2010 & 2011 & 2012 & 2013 & $\begin{array}{c}2014 \\
\text { Q3 }\end{array}$ & $\begin{array}{c}2014 \\
\text { Projections }\end{array}$ \\
\hline Real GDP rates & 10.7 & 6.9 & -5.7 & 2.5 & 3.2 & -2.5 & 3.3 & 1.3 & 2.5 \\
\hline $\begin{array}{l}\text { Unemployment rate } \\
\text { (\% of total workforce) }\end{array}$ & 11.92 & 10.74 & 11.43 & 12.16 & 11.57 & 13.43 & 14.88 & 13.61 & $\begin{array}{r}14.8 \text { (for eleven } \\
\text { months) }\end{array}$ \\
\hline $\begin{array}{l}\text { Inflation measured by Consumer Price } \\
\text { Index, } \%\end{array}$ & 7.7 & 7.2 & 1.5 & 0.7 & 2.8 & 5.1 & 0.3 & -0.7 & -0.5 \\
\hline Budget surplus/deficit* (\% of GDP) & 6.6 & 0.5 & -4.4 & -3.6 & -5.9 & -6.8 & -3.9 & -0.7 & -2.05 \\
\hline Public finance surplus/deficit (\% of GDP) & 6.3 & -0.4 & -5.7 & -4.9 & -5.4 & -6.1 & -2.6 & 0.3 & -1.4 \\
\hline Public debt (\% of GDP) & 27.5 & 29.0 & 38.2 & 40.9 & 45.9 & 54.0 & 57.95 & 58.1 & 60.2 \\
\hline
\end{tabular}

* The budget for 2008 includes the central budget with funds. For the purposes of data comparison, funds were added to the 2007 budget.

Source: $\mathrm{CBCG}$ and Ministry of Finance

Table 3: Key macroeconomic indicators in the Netherlands

\begin{tabular}{lrrrrrrrrr}
\hline & 2007 & 2008 & 2009 & 2010 & 2011 & 2012 & 2013 & $\begin{array}{c}2014 \\
\text { Projecions }\end{array}$ \\
\hline Real GDP rates & 3.9 & 1.8 & -3.7 & 1.5 & 0.9 & -1.2 & -0.8 & 0.2 \\
\hline Unemployment rate (\% of total workforce) & 4.5 & 3.8 & 4.8 & 5.4 & 5.4 & 6.4 & 6.7 & 7.1 \\
\hline Inflation measured by Consumer Price Index, \% & 1.6 & 2.5 & 1.2 & 1.3 & 2.3 & 2.5 & 2.5 & 0.5 \\
\hline Current account surplus/deficit o (\% of GDP) & 7.8 & 6.8 & 5.4 & 5.6 & 7.2 & 8.7 & 9.7 & 9.4 \\
\hline Public finances surplus/deficit (\% of GDP) & 0.2 & 0.5 & -5.5 & -5.0 & -4.3 & -4.0 & -2.5 & -2.7 \\
\hline Public debt (\% of GDP) & 45.3 & 58.5 & 60.8 & 63.4 & 65.7 & 71.3 & 73.5 & 74.3 \\
\hline
\end{tabular}

Sources: EUROSTAT, Statistics Netherlands, and DNB 
Tabela 4: Key macroeconomic indicators in Serbia

\begin{tabular}{lccccccccc}
\hline & 2007 & 2008 & 2009 & 2010 & 2011 & 2012 & 2013 & $\begin{array}{c}2014 \\
\text { Q3 }\end{array}$ \\
\hline Real GDP rates & 5.9 & 5.4 & -3.1 & 0.6 & 1.4 & -1.0 & 2.6 & -3.6 \\
\hline Inflation & 11.0 & 8.6 & 6.6 & 10.3 & 7.0 & 12.2 & 2.2 & 2.1 \\
\hline Unemployment & 18.1 & 13.6 & 16.1 & 19.2 & 23.0 & 23.9 & 22.1 & 17.6 \\
\hdashline Real fiscal deficit/surplus (\% GDP) & -1.6 & -1.9 & -3.1 & -3.3 & -3.9 & -5.4 & -4.5 & -2.4 \\
\hdashline Consolidated fiscal result & -1.9 & -2.6 & -4.2 & -4.5 & -4.7 & -6.1 & -4.7 & -3.2 \\
\hline Public debt & 29.9 & 28.3 & 32.8 & 41.8 & 45.4 & 56.2 & 59.6 & 67.9 \\
\hline
\end{tabular}

Source: NBS

Table 5: Key macroeconomic indicators and fiscal measures for overcoming the crisis

\begin{tabular}{|c|c|c|c|}
\hline & MONTENEGRO & SERBIA & THE NETHERLANDS \\
\hline $\begin{array}{l}\text { GDP at the end of } \\
2014 \text { (estimate) }\end{array}$ & $2.5 \%$ & $-1 \%$ & $0,2 \%$ \\
\hline $\begin{array}{l}\text { Fiscal deficit (target } \\
\text { and estimate for 2014) }\end{array}$ & $\begin{array}{l}\text { To } 2 \% \text { of GDP } \\
\text { Estimate: } 1.75 \% \text { of GDP }\end{array}$ & $\begin{array}{l}\text { Reduction } 1.5 \text { - } 2 \text { p.p. in } \\
\text { relation to deficit recorded } \\
\text { in } 2013 \text { Estimate: } 2.5 \text { at the } \\
\text { end of Q3 } 2014\end{array}$ & $\begin{array}{l}\text { Up to } 3 \% \text { BDP-a } \\
\text { Estimate: } 2,7 \% \text { BDP-a }\end{array}$ \\
\hline $\begin{array}{l}\text { Public debt, \% of GDP } \\
\text { (end of 2014) }\end{array}$ & $58 \%$ & $67.9 \%$ & $74.3 \%$ \\
\hline $\begin{array}{l}\text { Public debt (target) } \\
\% \text { of GDP }\end{array}$ & $\begin{array}{l}\text { Debt reduction, } 60 \% \text { of } \\
\text { GDP } \\
\text { In line with Maastricht } \\
\text { standard up to } 60 \% \text { of } \\
\text { GDP }\end{array}$ & $\begin{array}{l}45 \% \text { of GDP-a in line with } \\
\text { the Law on the Budget } \\
\text { System up to } 60 \% \text { of GDP-a } \\
\text { in line with Maastricht } \\
\text { standard }\end{array}$ & $\begin{array}{l}\text { Reduction, in line with } \\
\text { Maastricht standard up } \\
\text { to } 60 \% \text { of GDP-a }\end{array}$ \\
\hline $\begin{array}{l}\text { Inflation } \\
\text { (CPI - annual rate } \\
\text { 2014) }\end{array}$ & $-0.5 \%$ & $4 \%$ & $0.5 \%$ \\
\hline Real estate prices & $\begin{array}{l}\text { Sharp decline after the } \\
\text { crisis outbreak }\end{array}$ & $\begin{array}{l}\text { Sharp decline after the } \\
\text { crisis outbreak }\end{array}$ & $\begin{array}{l}\text { Sharp decline after the } \\
\text { crisis outbreak }\end{array}$ \\
\hline $\begin{array}{l}\text { Unemployment in } \\
2014 \text { (estimate) }\end{array}$ & $\begin{array}{l}14.8 \\
\text { (for } 11 \text { months) }\end{array}$ & Approximately $20 \%$ & $7.1 \%$ \\
\hline $\begin{array}{l}\text { Basic objective of the } \\
\text { fiscal consolidation } \\
\text { measures }\end{array}$ & $\begin{array}{l}\text { Reduction of fiscal deficit } \\
\text { and public debt }\end{array}$ & $\begin{array}{l}\text { Reduction of fiscal deficit } \\
\text { and public debt }\end{array}$ & $\begin{array}{l}\text { Reduction of fiscal deficit } \\
\text { and public debt }\end{array}$ \\
\hline
\end{tabular}

Source: Author's table based on data of relevant institutions of the selected countries

\subsubsection{Gross domestic product}

Although the smallest of the three countries, with the GDP growth of $3.3 \%$ in 2013, Montenegro was ahead of Serbia which recorded the growth rate of 2.6 and the Netherlands, which recorded a negative growth rate of $-0.8 \%$. Recent 
projections show positive economic growth rates in 2014 for Montenegro and the Netherlands, while Serbia's economic activity is in decline; mostly due to decline in the growth of foreign trade partners and the devastating consequences of extreme weather conditions recorded in May 2014 (NBS, 2014a).

Montenegro recorded significant GDP growth in the period 2006 - 2008, induced by the major inflow of foreign direct investments (FDIs) recorded after the restoration of the country's independence. Particularly expansive GDP growth was recorded in 2007 when it amounted to $10.7 \%$ of GDP, putting Montenegro among the fastest growing world economies. Economic growth followed by the increase in the FDIs inflow and credit boom (credit growth at the rate of over $100 \%$ in 2006 and 2007) generated a "bubble" in the capital and real estate markets, which burst at the end of 2008, transferring the effects of the global financial crisis onto the financial and economic system of Montenegro (Table 2). GDP growth projected for 2014 and 2015 amounts to $2.5 \%$ and $3.5 \%$, respectively (MF, 2014a).

As shown in Table 3, after the global crisis outbreak, economic activity in the Netherlands recorded a decline which reflected on GDP to decline more than $3 \%$ in 2009. Mild recovery was recorded over the following two years, when the Netherlands recorded positive economic growth rates, only to record decline in the economic activity again in 2012 and 2013. In 2014, economic activity finally slightly increased with the estimates that it shall amount to $0.2 \%$. (Table 3 ) Growth of $1.6 \%$ is estimated both in 2015 and 2016 (DNB, 2014b).

Gross domestic product in Serbia recorded a 2.6\% growth in 2013. In the precrisis period, annual GDP growth averaged at 5\%. After the crisis outbreak, BDP is in decline, amounting to $-3.5 \%$ at the end of 2009. Unfavourable events in Serbia in 2014, catastrophic floods in particular, induced the decline in the economic activity in Serbia. Therefore, GDP at the end of the third quarter of 2014 recorded a decline of $3.6 \%$ (Table 4 ).

\subsubsection{Unemployment}

Montenegro and Serbia are facing the issue of unemployment, which is higher in Serbia with the rate of $22.1 \%$ at the end of 2013 , and $14.88 \%$ in Montenegro. The recent data showed that in Serbia the unemployment rate is in decline, amounting to $17.6 \%$ at the end of the third quarter of 2014. As for the unemployment in Montenegro, the issue of the mismatch between the labour market demand and the supply of educated workforce has persisted for several years. The institutions of the system are directed towards an increase of employment and resolution of 
issues of uncoordinated workforce. At the end of the second quarter of 2014, unemployment amounted to $13.4 \%$.

In terms of the EU average, the Netherlands recorded a significant unemployment rate of $6.8 \%$ in 2013, and it is estimated that it shall amount to $7.1 \%$ in 2014 . The unemployment rate is expected to decline to $6.6 \%$ in 2016 . That said, the issue of unemployment in the Netherlands is by far less pronounced than in some other EU countries which have been recording unemployment rates of more than $25 \%$. The Dutch economy is still functioning below its potential and the high unemployment rate shows that the economy has not fully recovered (DNB, 2014a). However, compared to the unemployment rates in Montenegro and Serbia, the unemployment rate in the Netherlands is almost twice lower than in Montenegro and almost three times lower than in Serbia (Table 5).

\subsubsection{Inflation}

As for the prices, Serbia recorded inflation rates at the end of 2012, reaching no less than $12 \%$. The National Bank of Serbia had to resort to depreciating the dinar in order to lower inflation. This had the desired effect, and the inflation was reduced from 11\% in Q1 2013 to 2.2\% at the end of the year (Table 4). Inflation increase occurred because of increases in the prices of food, consumption tax, and similar, as well as on the demand side due to the application of fiscal measures and strong deprecation. Since the maintaining of price stability is the National Bank of Serbia's key objective, it responded by applying restrictive monetary policy measures, namely by raising the interest rate and intervening in the foreign exchange market (NBS, 2013a). The year 2014 was marked by low inflation rates, due to a reduction of the prices of food and a decline in aggregate demand, resulting in inflation dropping to $2.1 \%$ at the end of Q3 2014 (Table 4).

The Netherlands also recorded a decline in inflation, mostly due to an increase in income tax. In 2012 and 2013, inflation amounted to 2.5\%. In January 2013, the prices recorded an increase of $3 \%$, placing the Netherlands among the EU countries with the highest inflation rates. The prices increase was a result of the increase in the prices of oil and value added tax. Average inflation for 2013 was $2.2 \% .{ }^{8}$ Projections are that inflation will be 0.5 and $0.7 \%$ in 2014 and 2015 respectively (DNB, 2014a).

8 http://statline.cbs.nl/StatWeb/publication/?DM=SLEN\&PA=70936eng\&D1=0-1\&D2=(1-13)$1 \& \mathrm{LA}=\mathrm{EN} \& \mathrm{VW}=\mathrm{T}$ 
Inflation downtrend in Montenegro continued in 2013. Accordingly, the prices growth at the beginning of 2013 amounted to $3.2 \%$, declining to $0.3 \%$ at the end of the year. The annual inflation rate in 2013 amounted to $2.2 \%$. As for 2014, the year was marked by negative inflation rates, therefore it is expected that inflation will range between $-0.5 \%$ and $0.6 \%$ at the end of the year (CBCG, 2014a).

\subsubsection{Fiscal deficit and public debt}

The fiscal deficit and the level of public debt pose a problem for all three countries. Fiscal consolidation measures that have been taken by the Governments of the observed countries are implemented with the same goals: reducing fiscal deficit and halting the public debt growth. The situation in Serbia is similar to the one in Montenegro because the dynamics of public debt poses a reason for concern. Fiscal consolidation measures yielded positive effects viewed in stabilising public consumption and improving the collection of revenues.

In 2012, the Dutch fiscal deficit amounted to 4\% of GDP. Despite negative trends in the economy, it was reduced to the level of $2.5 \%$ of GDP at the end of 2013. For 2014 and 2015, it is predicted that the deficit will amount to $2.7 \%$ and $2.2 \%$ of GDP, respectively. After a significant decline of deficit in 2013, there was a small growth in 2014 (DNB, 2014a). The Dutch public debt increased from 45\% of GDP in 2007 to as much as $73.5 \%$ of GDP at the end of 2013(Table 3).

In Serbia, the government has been increasingly financing the deficit through foreign borrowing, thus affecting the growth of the public debt which sustainability is called into question primarily due to the exposure to foreign exchange risk. However, the government borrowing in the international market enables the private sector to borrow in the domestic market. The public debt has been increasing primarily as a result of financing the current and fiscal deficit, issuance of government guarantees for public enterprises and repayment of principals that are due in the upcoming periods (NBS, 2013). As the Table 3 shows, the public debt increased during all of the observed periods, amounting to 59.6\% of GDP at the end of 2013 and 67.9\% of GDP at the end of Q3 2014.

In 2007, Montenegro recorded a fiscal surplus of $6.6 \%$, while it amounted to $0.5 \%$ in 2008. Since 2009, the budget of Montenegro has been recording negative results. In 2013, the fiscal deficit amounted to 3.9\% of GDP. According to the Ministry of Finance projections for 2014, the deficit should reduce below 2\% of GDP. From the aspect of fiscal stability of Montenegro, the importance of fiscal deficit is enormous. Fiscal deficit spills over to public debt, causing it to increase, which in turn has a significant influence on the stability of public finances. Sustain- 
ability of public finances is conditioned by the amount of public debt, primarily by the possibility of its repayment. Montenegro's public debt remains within the limits set by the Maastricht criteria, but its dynamics is a matter of significant concern. At the end of 2013, the public debt doubled in relation to 2008 (Table 2).

\subsection{Financial system}

The most important influence in terms of preserving financial stability in all of the compared countries is attributed to trends in the financial system, especially in the banking sector. When it comes to financial stability, the influence of the non-banking sector is negligible compared to the influence of the banking sector.

Special emphasis is placed on credit risk which proved to be the most significant from the aspect of preserving financial system. During the crisis years, lending activity of banks declined. However, recent data shows a slight recovery in the Netherlands, which indicates an increase of trust in the banking sector, and consequently the financial system. In Montenegro, total loans recorded a decline, but new lending increased. However, there has been an upward trend of deposits in Montenegro, which is an evidence of the safety of the banking sector. Serbia continues to record a downward trend in lending activity. One of the key challenges that the countries face in the post-crisis period is regaining trust in the banking system and its institutions.

\subsubsection{Banking system}

\subsubsection{Risks}

\section{a. Credit risk}

Credit risk is very pronounced in all three cases. In Montenegro and Serbia, credit risk poses the greatest threat to financial system, as can be seen through the high level of non-performing loans (NPLs). Table 6 shows the situation of nonperforming loans in relation to total loans. When it comes to the Netherlands, the level of NPLs is not a matter of concern, but there is a pronounced credit risk. This is because due to the crisis, lower prices of real estate, lower values of mortgage collateral, reduced economic growth, and poor economic conditions the banks need to allocate significant provisions. 
Table 6: Gross non-performing loans to total loans

\begin{tabular}{lrrrrrrrr}
\hline & 2008 & 2009 & 2010 & 2011 & 2012 & 2013 & $\begin{array}{l}2014 \\
\text { (Q2) }\end{array}$ \\
\hline Montenegro & 7.2 & 13.52 & 20.97 & 15.53 & 17.6 & 18.38 & 17.91 \\
\hdashline Netherlands & 1.68 & 3.2 & 2.82 & 2.71 & 3.1 & 3.23 & 3.0 \\
\hdashline Serbia & 11.3 & 15.7 & 16.9 & 19 & 18.6 & 21.4 & 23 \\
\hline
\end{tabular}

Source: Author's table based on data of relevant institutions of the selected countries

Montenegro - In the banking system of Montenegro, stress testing showed the highest exposure of the system to credit risk. What is particularly worrying is the high level of NPLs, which at some point exceeded $20 \%$ in relation to total loans (Table 6). The problem of deteriorating loan portfolios has been evident since the onset of the financial crisis. Expansive lending policy which characterised the period that preceded the crisis was stopped once the crisis broke out. In 2007, lending activity increased by $165 \%$ in relation to 2006 . However, since the crisis outbreak, lending activity has been drastically reduced. In order to improve their loan portfolios, banks used the measures that included migration of nonperforming loans into balance sheets of parent banks, sale and restructuring of loans. The project Podgorica Approach, which was mentioned earlier, was created as one of the models for NPL resolution. In 2013 and 2014, banks continued to face the problem of non-performing assets. It is encouraging that the percentage of NPLs declined in 2014 (Table 6). In recent years, the system has been recovering from the crisis, as evidenced by an increase in new loans and deposits.

The real economy represents the main source of credit risk. Compared to the household sector, the amount of past due loans in the corporate sector is significantly higher. During the boom period in 2007, a large number of loans were placed for the purpose of investing in real estates, which recorded extremely high prices. Because of high demand, banks had to borrow in order to meet the growing demand. Of course, the increase of lending activity was in the interest of the banks themselves. This situation lasted until Q3 2008 and it was followed by a withdrawal of deposits as a result of bad situation in individual banks and unfavourable global trends. The crisis caused a major decline in real estate investments and left serious consequences in the financial sector which was characterised by loose behaviour, because the banks were rather careless and engaged in excessive lending over a short period of time, without considering the endogenous factors of the system (CBCG, 2013a). However, driven by the negative experience from the previous period, the banks made their lending standards more rigid in order to protect themselves from potential risks and losses. 
Serbia - Credit risk has been identified as the most important risk in the banking sector. During the pre-crisis period, from 2006 until 2008, lending activity grew at the rate of $45.1 \%$ and in the period between 2009 and 2012 the growth averaged at $7.3 \%$. At end-2012, credit growth declined to $1.5 \%$ (NBS, 2013a).

Lending activity also declined during 2013. The amount of granted loans declined by $4 \%$ in relation to 2012 (NBS, 2014a). Lower economic growth and tightening of lending standards had a significant influence on the decline of lending activity and reduced demand. High level of non-performing loans is particularly present in construction companies due to a high risk of price fluctuations as a result of poor valuation of real estates. High level of loan loss provisioning is necessary when non-preforming loans represent a burden for banks. At the beginning of the crisis in 2008, Serbia recorded a rather high share of non-performing loans of $11.3 \%$. When it comes to loans granted to households, the lowest default rate is recorded by housing loans. In terms of supply, there is still a high level of prudence when granting loans as a result of economic crisis and increased resilience of banks to risk exposure. Also, there is the already mentioned change in the model of parent banks, where subsidiaries are becoming increasingly dependent on domestic sources of funding. Subsidiaries of European banks have a 75\% share in the domestic market. A decision whether the parent banks will be willing to lend to domestic economy depends on the macroeconomic situation in Serbia, as well as opportunities for making profit (NBS, 2013a).

The Netherlands - growth of credit risk is particularly pronounced in the domain of increased debt write-offs, with a higher amount of written-off debt to enterprises compared to households. This situation comes as a consequence of economic crisis which caused many clients not to be able to meet their obligations to banks. The Netherlands does not have a high level of non-performing loans, as shown in Table 6.

Bank lending to households is still quite weak. Banks have tightened their credit standards. They have become hesitant to grant loans. Banks are performing the way they are preventing from risks and at the same time are limiting their lending not only because of risks but to strengthen their balance sheets. It is important to mention that banks continued to act this course in 2014. The primary reason they are strengthening their capital position is in order to meet higher standards and requirements of Basel III until 2019. (DNB, 2014a) 


\section{b. Liquidity risk}

The banking sectors of all three countries are highly liquid, especially in the Netherlands. Stress testing is performed to assess liquidity risk, which may result from the loss of depositors' trust as well as from poor economic conditions. Since 2008 , the liquid assets to short-term liabilities ratio has been exceeding $150 \%$ of coverage in all reporting periods (Table 8).

In the banking system of Serbia, liquidity risk does not threaten the stability of the financial system. According to test results, the banking system is liquid even in the case of maximum presumed withdrawal of deposits. In case of that scenario, a certain number of banks would be in the zone of high liquidity risk.

Liquidity risk is not pronounced in the banking system of Montenegro, particularly if one considers that the banks operated with extreme caution and conducted a restrictive policy, which resulted in an increase in the banks' monetary assets and overall liquidity. During 2014, all banks in the banking system of Montenegro were liquid. The share of liquid assets in total assets amounted to $19.9 \%$ at the end of December 2013, while it amounted to $18.82 \%$ at the end of the second quarter of 2014. Compared to short-term liabilities, the liquid assets amounted to $32.19 \%$ and $29.61 \%$ in 2013 and 2014, respectively. It should be noted that the banking sector in Montenegro is highly liquid, but there is still a problem of liquidity shortfalls in the real sector.

Table 7: Liquid assets to total assets

\begin{tabular}{lrrrrrrrr}
\hline & 2008 & 2009 & 2010 & 2011 & 2012 & 2013 & $\begin{array}{c}2014 \\
\text { Q2 }\end{array}$ \\
\hline Montenegro & 11.2 & 15.26 & 19.11 & 19.93 & 24.03 & 19.99 & 18.82 \\
\hline Netherlands & 21.67 & 25.77 & 24.51 & 24.84 & 24.31 & 23.6 & 22.11 \\
\hdashline Serbia & 43.3 & 41.5 & 35.1 & 37.8 & 34.5 & 38.5 & 38 \\
\hline
\end{tabular}

Source: Author's table based on data of relevant institutions of the selected countries

Table 8: Liquid assets to short-term liabilities

\begin{tabular}{lrrrrrrrr}
\hline & 2008 & 2009 & 2010 & 2011 & 2012 & 2013 & $\begin{array}{c}2014 \\
\text { Q2 }\end{array}$ \\
\hline Montenegro & 20.89 & 25.84 & 32.87 & 32.78 & 40.13 & 32.19 & 29.61 \\
\hline Netherlands & 187.35 & 187.35 & 173.91 & 175.77 & 179.48 & 180.26 & 165.53 \\
\hdashline Serbia & 68.6 & 63.6 & 56.4 & 62.8 & 57.5 & 62.2 & 61.3 \\
\hline
\end{tabular}

Source: Author's table based on data of relevant institutions of the selected countries 


\section{c. Market risk}

Both in Serbia and Montenegro market risks are negligible, while the Dutch banking system is exposed to interest rate risk. Risk of interest rate changes, in the sense of trading activities, hardly exists in the Montenegrin banking sector because trading positions that would potentially be affected by interest rate changes are insignificant. In the Montenegrin banking system, FX risk is low primarily as a result of the euroised economy as well as the proper management of this risk. The majority of loans are denominated in euros (CBCG, 2013).

In Serbia, market risks are low. This is best confirmed by the amount of capital requirements of $1 \%$ for market risks. Most securities held by banks in their portfolios represent securities of the National Bank of Serbia or government securities. FX risk indicator was $3.3 \%$ in late 2013, far below the regulatory minimum of $20 \%$. Market risk may represent a problem for debtors who borrow in foreign currency and receive their salary in RSD. When granting loans, the banks hedged against FX risk by extending FX clause indexed loans. Potential vulnerability of unhedged clients is fed back to banking sector balance sheets as an FX-induced credit risk (NBS, 2013a).

Important feature of Dutch banks is that they are very dependent on market funding. This dependence is lowering in recent years. Therefore, the loan to deposit ratio decreased from $200 \%$ before the crisis to $170 \%$ in 2014 . Banks are lending more money to households and business than they are receiving in the form of savings deposits. The banks have a high level of mortgage debt. In order to finance it, banks raise money in the international capital market. This makes them vulnerable to the financial market unrest, which can be mitigated by reducing the deposit funding gap and making them easier to finance (DNB, 2013c).

\section{d. Operational risk}

In all three selected countries, the central banks manage payment systems and are responsible for their proper functioning. Financial stability can be compromised if the functioning of these systems is interrupted.

In Montenegro, all operational risks involving the payment system have been minimised by means of technical and legal solutions. What would further improve its security is the establishing of a disaster recovery location (CBCG, 2014a). In the Netherlands, financial institutions face cyber threats which is the reason why they continuously work to strengthen the infrastructure and protection mechanisms (DNB, 2013d). In Serbia, special attention is paid to ensuring a strong and efficient infrastructure. Therefore, in 2013, stress testing was con- 
ducted and it showed that payment system and clearing system availability was $100 \%$ (NBS, 2014a).

\subsubsection{Capital adequacy}

During the observed years, the capital adequacy ratio was above the statutory minimum in all three countries (Table 9). In Montenegro, the minimum statutory capital adequacy ratio is $10 \%$ while in Serbia and the Netherlands it amounts to $12 \%$ and $8 \%$, respectively.

The capital adequacy ratio at the banking sector level in Montenegro is above the statutory minimum, and it amounted to $14.71 \%$ at the end of 2012 . This coefficient amounted to $14.41 \%$ at the end of 2013. In Serbia, the capital adequacy ratio exceeds statutory minimum of $12 \%$ during all of the observed periods. The Dutch banking sector is adequately capitalised and amounted to $14.89 \%$ at the end of 2013 and 17.29\% at the end of Q3 2014 (Table 9). In accordance with the Basel standards, the prescribed minimum capital adequacy ratio is $8 \%$.

Table 9: Capital adequacy -Regulatory capital to risk weighted assets

\begin{tabular}{lrrrrrrrr}
\hline & 2008 & 2009 & 2010 & 2011 & 2012 & 2013 & $\begin{array}{c}2014 \\
\text { Q2 }\end{array}$ \\
\hline Montenegro & 15.04 & 15.75 & 15.85 & 16.51 & 14.71 & 14.44 & 15.83 \\
\hdashline Netherlands & 11.86 & 14.91 & 13.91 & 13.48 & 14.23 & 14.89 & 17,29 \\
\hdashline Serbia & 21.9 & 21.4 & 19.9 & 19.1 & 19.9 & 20.9 & 20.4 \\
\hline
\end{tabular}

Source: Author's table based on data of relevant institutions of the selected countries

\subsubsection{Profitability of the banking sector}

Since the beginning of the financial crisis, the Montenegrin banking sector has been recording negative financial results, as evidenced by negative ROA and ROE rates. In 2013, the banking sector managed to finish the year with profit and that trend continued in 2014. Unlike Montenegro, the banking sector in Serbia operated with profit, regardless of the crisis. In 2013, for the first time since the crisis onset, it recorded a negative financial result. However, the Serbian banking sector recorded profit in 2014. The Dutch banking sector recorded a negative result in 2008, after which it recorded positive results until 2012, when it operated without profit. The Dutch banking sector showed positive results in 2014 (Tables 10 and $11)$. 
Table 10: Return on assets (ROA)

\begin{tabular}{lrrrrrrrr}
\hline & 2008 & 2009 & 2010 & 2011 & 2012 & 2013 & $\begin{array}{c}2014 \\
\text { Q2 }\end{array}$ \\
\hline Montenegro & -0.62 & -0.68 & -2.76 & -0.11 & -2.02 & 0.07 & 0.98 \\
\hline The Netherlands & -0.96 & 0 & 0.32 & 0.24 & -0.01 & -0.03 & 0,1 \\
\hdashline Serbia & 2.1 & 1.0 & 1.1 & 0.0 & 0,4 & -0.1 & 1.0 \\
\hline
\end{tabular}

Source: Author's table based on data of relevant institutions of the selected countries

Table 11: Return on equity (ROE)

\begin{tabular}{lrrrrrrrr}
\hline & 2008 & 2009 & 2010 & 2011 & 2012 & 2013 & $\begin{array}{c}2014 \\
\text { Q2 }\end{array}$ \\
\hline Montenegro & -6.9 & -7.77 & -27.27 & -1.08 & -18.32 & 0.49 & 6,84 \\
\hdashline Netherlands & -29.86 & 0 & 7.14 & 5.4 & -0.13 & -0.73 & 2,19 \\
\hline Serbia & 9,3 & 4.6 & 5.3 & 0,2 & 2,0 & -0.4 & 5,0 \\
\hline
\end{tabular}

Source: Author's table based on data of relevant institutions of the selected countries

\subsubsection{Compliance with the Basel standards}

Compliance with Basel III requires demanding provisioning and capital requirement practices. The Netherlands is already largely aligned with Basel III, and it is estimated that it will meet the deadline for full harmonisation set for 1 January 2019. Montenegro is harmonising its regulations with Basel II. Serbia harmonised its regulations with Basel II. In December 2013, the Strategy for implementation of Basel III standards in Serbia was adopted.

Compliance with the Basel standards in Montenegro - Regulatory activities regarding harmonisation of banking regulations in Montenegro with Basel II were initiated with the adoption of the new Banking Law in 2008 and a set of regulations for its enforcement. As the most significant by-law, Decision on Capital Adequacy of Banks was adopted in 2011. The decision also includes guidelines on the process of internal assessment of capital adequacy of banks and guidelines for supervisory review process. With the adoption of the abovementioned Decision and Guidelines, the regulations of the Central Bank are fully complied with the Basel Capital Accord, Pillars I and II, except for the part referring to advanced approaches for calculating capital requirements for credit and operational risk. The adoption of the Decision on public disclosure of data and information by banks in December 2011 provides harmonisation of the CBCG regulations with Directive 2006/48/EC (Annex VII - Technical criteria on disclosure). In this way, the 
banking legislation included Basel Capital Accord, Pillar III. With the adoption of the Decision on the manner of calculating bank exposures, the regulations of the Central Bank are complied with the Directive 2009/111. Speaking in general, we can say that the regulations governing the banking sector have been largely harmonised with Basel II. As already stated, harmonisation of legislation with the EU acquis represents an ongoing process which requires addition harmonisation stemming from frequent changes of directives. Regulatory activities of the Central Bank, referring to the banking sector in 2013, predominantly aimed at further harmonisation of the secondary legislation with relevant directives of the EU, particularly Directive 2008/48/EC on credit agreements for consumers, as well as at further improvement of the existing regulatory framework, especially regulation governing credit risk management in banks. The new Banking Law, which will be harmonised with Basel III, is planned to be adopted by the end of 2015, and it would come into force as of 1 January 2017 (CBCG).

Compliance with the Basel standards in Serbia - The National Bank of Serbia adopted the Decision on Capital Adequacy and thus completed a package of regulations that needed to be harmonised with Basel II. In December 2013, the National Bank of Serbia adopted a Strategy for introducing Basel III standard. According to the Strategy, the introduction of Basel III will be implemented in three phases. The first phase is preparation and includes the first three months of 2014. It refers to the implementation of analysis of (non)compliance with the Basel III requirements, and setting out the operational plan of activities for the implementation of standards. The second phase refers to the assessment of effects and establishment of implementation dynamics and it is planned until the end of 2014. The third phase refers to legislation drafting and its completion is planned for the end of 2015(NBS, 2013b).

Compliance with the Basel standards in the Netherlands - In the Dutch financial system, the banks are implementing Basel III. As a result of a slow recovery from the financial crisis, it is expected that the standards will be implemented during the next couple of years. As already mentioned, the EU countries should harmonise their standards with Basel III by 1 January 2019. According to data as at the end of 2013, Dutch banks need additional 20 billion euros in hybrid capital (DNB, 2014b).

\subsubsection{Non-banking sector}

The Netherlands - In this country, the pension funds are highly developed. The Dutch pension system is considered to be one of the best in the world. However, the pension funds invested in risky securities, making their portfolio highly risky. 
As part of fiscal consolidation measures, the Netherlands has been implementing activities aimed at adjusting and reforming the pension insurance system. The insurance sector has pronounced market risks. Longer periods of low interest rates have negative effects on the capital of pension funds and insurance companies. Their financial positions are influenced by adverse effects of the decline of interest rates. The effects are immediately visible because the Dutch insurance companies and pension funds value their balance sheets at market values. Low interest rates make the insurance policies expensive for insurers (DNB, 2013a).

Serbia - The insurance and pension funds do not have a significant influence on the stability of financial system in Serbia. The insurance sector remains to be underdeveloped, and its share in the financial sector's total assets and liabilities amounted to $4.8 \%$ at the end of 2013. Net assets of voluntary pension funds in the total assets and liabilities of the financial sector are very small, and investment policies of the voluntary investment funds are rather conservative. In 2013, 96\% of their assets were invested in the government securities of Serbia. Development of domestic capital market represents a prerequisite for development of voluntary pension funds (NBS, 2014a).

In Montenegro, the micro-credit financial institutions (MFIs), capital market and insurance sector do not have a significant influence and cannot jeopardise stability of the financial system. There is a negligible influence of MFIs on financial stability, primarily as a result of their share in the market. Also, MFIs do not have a legal possibility of receiving deposits, and there is no danger of outflow of deposits. The capital market has a negligible influence in terms of financial stability, primarily because it is underdeveloped and has a small amount of capital that is provided in this way. The economy borrows the capital from banks in the form of loans. The insurance sector cannot significantly affect financial stability, primarily due to its size. However, as with the capital market, this is where we should also look for opportunities to expand the market (CBCG, 2014a).

Dependence on bank financing can be reduced by giving a greater role to institutional investors. Investment and pension funds can reduce the lending problems by purchasing bank securities and government bonds. The non-banking lenders can borrow funds to households or for business development. Funds can be invested in medium and small enterprises, which in turn stimulates the production and economic growth.

The following table provides a short analysis by comparing the situation in the financial systems of Montenegro, Serbia and the Netherlands. 
Table 12: Comparison - Financial system

\begin{tabular}{|c|c|c|c|}
\hline & Montenegro & Serbia & The Netherlands \\
\hline \multicolumn{4}{|c|}{ Banking sector } \\
\hline Major risks & Credit risk & Credit risk & $\begin{array}{l}\text { Credit risk and interest } \\
\text { rate risk }\end{array}$ \\
\hline Credit risk & High & High & High \\
\hline $\begin{array}{l}\text { Lending activity of } \\
\text { banks }\end{array}$ & $\begin{array}{l}\text { Decreased since the } \\
\text { outbreak of the crisis, slight } \\
\text { increase of new loans }\end{array}$ & $\begin{array}{l}\text { Decreased since the } \\
\text { outbreak of the crisis }\end{array}$ & $\begin{array}{l}\text { Decreased since the } \\
\text { outbreak of the crisis }\end{array}$ \\
\hline Liquidity risk & Not high & Not high & Not high \\
\hline Market risks & Not high & Not high & High interest rate risk \\
\hline Operational risk & Continuously monitored & Continuously monitored & Continuously monitored \\
\hline $\begin{array}{l}\text { Capital adequacy ratio } \\
\text { at end-Q2 } 2014\end{array}$ & $\begin{array}{l}15,83 \% \\
\text { Statutory minimum: } 10 \%\end{array}$ & $\begin{array}{l}20,4 \% \\
\text { Statutory minimum: } 12 \%\end{array}$ & $\begin{array}{l}17,29 \% \\
\text { Statutory minimum: } 8 \%\end{array}$ \\
\hline Problems with NPL & High & High & Not high \\
\hline $\begin{array}{l}\text { NPL in total loans at end } \\
\text { Q2 } 2014\end{array}$ & $17.91 \%$ & $23 \%$ & $3 \%$ \\
\hline Banking sector liquidity & Liquid & Liquid & Liquid \\
\hline $\begin{array}{l}\text { Profitability at the } \\
\text { sector level }\end{array}$ & Positive financial result & Positive financial result & Positive financial result \\
\hline Compliance with Basel & $\begin{array}{l}\text { Highly harmonised with } \\
\text { Basel II }\end{array}$ & $\begin{array}{l}\text { Harmonised with Basel II, } \\
\text { Began preparations for } \\
\text { harmonisation with Basel III }\end{array}$ & $\begin{array}{l}\text { Harmonisation with } \\
\text { Basel III standards }\end{array}$ \\
\hline \multicolumn{4}{|c|}{ Non-banking sector } \\
\hline Insurance sector & Developing & Developing & Developed \\
\hline Voluntary pension funds & Developing & Developing & Developed \\
\hline Capital market & Developing & Developing & Developed \\
\hline
\end{tabular}

\section{Conclusion}

A stable financial system represents a precondition for economic development and growth. It is extremely challenging for every country to build a trust in the financial system and even more so to maintain it, especially under difficult conditions following the global financial crisis. In order to maintain financial stability, monetary and economic policy creators need to analyse and use monetary and economic policy measures to prevent everything that may pose a threat to stability of the financial system. Therefore, it is necessary to create such financial infrastructure and mechanisms that will enable early identification of problems and prevent the spillover from one financial institution to the entire financial system as well as to other sectors in the economy. 
The global financial crisis showed that the monetary policy creators face numerous challenges in terms of long term recovery. These challenges include resolution of non-performing loans, development of a quality defence system against risks and financial imbalances as well as development of a resilient and sustainable financial system. One of the most important objectives in the process of resolving banking crises is regaining credibility of the banking and financial system. This paper pointed out that the European Union is building mechanisms aimed at creating a stable system, capable of responding to all challenges and shocks. In order to maintain a stable financial system, the monetary authority (central bank and/ or competent supervisory institution) is expected to: carefully control operations of all financial institutions under its jurisdiction through the process of supervision, harmonise regulatory framework with international standards, perform stress testing of banks to potential risks, take preventive actions and monitor the implementation of necessary measures. In case of a crisis, there needs to be a synergy between all institutions responsible for maintaining safety and stability of the financial system. Although the central bank represents one of the main guardians of the financial system's stability, it cannot be solely responsible for financial stability or instability in any county. The governments need to create a good economic and business environment, as well to increase economic growth and competiveness.

The financial crisis showed that even the developed countries have weaknesses, and that being a resident of an economically developed country, such as the Netherlands, does not imply a complete protection against financial, structural and existential problems. The crisis unified the problems that are faced by both advanced and emerging countries. By creating the single supervisory mechanism and the single resolution mechanism, the European Union aims to achieve a full integration and create the single financial market, thus building a safe path to creating the European Banking Union.

Unlike the central banks of Serbia and the Netherlands, the key objective of the Central Bank of Montenegro is to achieve financial stability. In Serbia, as well as the Netherlands, the central banks are committed to preserving financial stability, but their key objective is price stability. Even though they are different in many ways, the economies of Serbia, the Netherlands, and Montenegro all face consequences of the financial crisis, including slow economic recovery, rising unemployment, significant fiscal deficits, and growing public debts.

In the banking system of all three countries, credit risk is considered the most important and potentially the biggest risk. Fiscal adjustment represents a necessity because it is directly related to debt sustainability. Although it is a small and open 
economy, Montenegro faces problems that represent obstacles even for developed countries like the Netherlands. As a consequence of the global financial crisis, all three countries had to use fiscal consolidation measures because it was necessary to increase budget revenues and decrease the corresponding expenditures, thus reducing the fiscal deficit. To that end, Montenegro increased VAT from $17 \%$ to $19 \%$ and the Netherlands rose it from $19 \%$ to $21 \%$. Increase in fiscal expenditures coupled with inadequate level of revenues leads to an increase of deficit and creates the need for further borrowing in order to finance liabilities, which in turn affect the growth of the public debt. Financing through borrowing is acceptable to a certain level, especially if it refers to new investments. However, if it involves a policy of financing debt and current expenditures through new borrowing, it needs to be stopped because it may jeopardise sustainability of public finances. In the case of Montenegro, the reason for concern lies in the level of the public debt, especially its growth dynamic. Since 2008, the public debt doubled. This trend needs to be stopped, while the economic growth and competiveness of the economy need to be encouraged. The situation is similar in the respective neighbouring country Serbia, as well as in the Netherlands.

Fiscal adjustment is a rigid and highly unpopular measure in the short-term. However, in terms of sustainability of public finances it is a necessary measure especially since it influences stabilisation and growth in the medium- and longterm. When it comes to solving the problem of fiscal deficit, all three countries made ambitious plans for 2014. Montenegro and Serbia planned to use fiscal consolidation measures to increase the collection of revenues and decrease expenditure, thus reducing the respective deficits below $2 \%$, while the Netherlands' plan is below 3\%. The latest data indicate that those objectives have been fulfilled as the Netherlands has managed to reduce the level of fiscal deficit below $3 \%$, Montenegro below 2\%, while in Serbia it was also reduced in relation to 2013.

The most prominent risk in the banking sector in all three countries is credit risk. Taking into account macroeconomic environment, low and/or negative growth rates, increased taxes and unemployment problems, which affect the reduction of personal income, the risk of repayment of granted loans is increased. What is particularly worrying is the level of non-performing loans in both Serbia and Montenegro so at the end of the second quarter of 2014, non-performing loans amounted to $23 \%$ and $17.91 \%$, respectively. The Netherlands does not have a problem with high levels of NPLs, but the banks significantly tightened their lending criteria and became highly demanding when approving loans, in order to increase their capital and meet all Basel standards. When it comes to managing non-performing loans, monetary authorities in Montenegro and Serbia are working hard to find a solution to reduce non-performing assets. To that end, 
Montenegro initiated the Podgorica Approach and Serbia started with the Belgrade initiative. Unlike Serbia, Montenegro is not a signatory to the Vienna Initiative and, therefore, it has not been able to use the facilities provided under this initiative to combat the effects of the financial crisis in the region as well in terms of the level of credit exposure of parent banks.

In order to efficiently identify and overcome risks, the respective countries created regulatory frameworks that are in line with international and/or the EU regulations. The Netherlands is a member of the EU and the euro area, while Montenegro and Serbia are in the process of fulfilling the conditions to become members of the EU. The mechanism created by the EU as well as its activities aimed at strengthening the financial system with a view to safeguarding financial stability showed that once Montenegro and Serbia have become full-fledged members of the EU, they will also have access to the aforesaid funds through the membership in initiatives, pacts, and the banking union.

Progress in the area of financial stability is not easy to predict and there is no universally accepted definition of financial stability. It is impossible to determine the state of financial stability solely on the basis of existing risks and identified disturbances. It is also essential to identify potential shortcomings and problems that may occur in the future.

Financial crises are difficult to predict, and their effects have serious consequences on the financial system and the economy. Thus, the policy creators learned a lesson from bitter experiences during the global financial crisis that have raised awareness of the importance of financial stability and confirmed that a stable financial system represents the key element for a sound and successful economy. 


\section{References:}

1. Central Bank of Montenegro (2013), Financial Stability Report, CBCG

2. Central Bank of Montenegro (2014a), Financial Stability Report, CBCG

3. Central Bank of Montenegro (2014b), Inflation Report, CBCG

4. Central Bank of Montenegro Law (OGM no. 40/10, 46/10. 6/13)

5. Constitution of Montenegro(OM no. 1/07)

6. De Nederlandsche Bank (2013a), Annual Report, DNB

7. De Nederlandsche Bank (2013b), Economic Developments and Outlook, June 2013, no. 5, DNB

8. De Nederlandsche Bank (2013c), Overview of Financial Stability, Spring 2013, DNB

9. De Nederlandsche Bank (2013d), Overview of Financial Stability, Autumn, 2013, DNB

10. De Nederlandsche Bank (2014a), Economic Developments and Outlook, June 2014, no. 7, DNB

11. De Nederlandsche Bank (2014b), Overview of Financial Stability, Autumn 2014, no. 20, DNB

12. Ferguson, Roger (2002), Should Financial Stability Be An Explicit Central Bank Objective?, Challenges to Central Banking from Globalized Financial Systems, IMF Conference, Washington, D.C., Retrieved from: https://www. imf.org/external/pubs/ft/seminar/2002/gfs/eng/ferguson.pdf

13. Financial Stability Council Law (OGM no. 44/10)

14. Fiscal Council, Retrieved from: http://www.fiskalnisavet.rs/lat/fiskalnapravila

15. Government of the Netherlands (2013), Effective Action Report 2013, Amsterdam, Retrieved from: http://www.government.nl/documents-andpublications/publications/2013/09/30/effective-action-report-2013.html

16. Government of the Netherlands (2014), Stability Programme of the Netherlands, Retrieved from: http://ec.europa.eu/europe2020/pdf/csr2014/ sp2014_netherlands_en.pdf

17. Ministry of Finance, Montenegro (2013), Information on Fiscal Consolidation for Nine Months in 201 with Future Measures Recommendation, Podgorica

18. Ministry of Finance, Montenegro (2013b), Information on Macroeconomic projections for Montenegro 2014- 2016., Podgorica

19. Ministry of Finance, Montenegro, MF (2014a), Macroeconomic and Fiscal Indicators Forecast for 2014-2018, updated version, Podgorica

20. Ministry of Finance, Montenegro, MF (2014b), Macroeconomic and Fiscal Policy Directions 2014-2017, Podgorica 
21. Ministry of Finance, Montenegro, MF (2014c), Press Release, Retrieved from: http://www.mf.gov.me/rubrike/kreditni-rejting-crne-gore/143626/ SAOPsTENJE-Standard-and-Poor-s-snizio-kreditni-rejting-Crnoj-Gori.html

22. Mishkin, Frederic S. (1999), Global Financial Instability: Framework, Events, Issues, Journal of Economic Perspectives, 13(4),3-20, Retrieved from: https:// www.unc.edu/ salemi/Econ006/Mishkin_Global_Financial_Instability.pdf

23. Moody's (2014), Retrieved from: https://www.moodys.com/research/ Moodys-changes-outlook-on-the-Netherlands-Aaa-government-bondrating--PR_294381

24. National Bank of Serbia (2013a), Annual Financial Stability Report, NBS

25. National Bank of Serbia(2013b), Strategy for Implementation of Basel III Standards in Serbia, http://www.nbs.rs/export/sites/default/internet/ english/55/55_2/55_2_7/Strategija_BazelIII_e.pd

26. National Bank of Serbia(2014a),Annual Financial Stability Report, NBS

27. National Bank of Serbia (2014b), Inflation Report, NBS

28. Schinasi, Garry J. (2005), Safeguarding Financial Stability, Theory and Practice, Washington D.C.:IMF

29. Government of Serbia (2013), Fiscal Strategy for 2014 with Projections for 2015 and 2016

\section{Websites:}

30. http://www.cbcg.me

31. http://www.dnb.nl

32. http://www.ecb.europa.eu/pub/fsr/html/index.en.html

33. http://epp.eurostat.ec.europa.eu

34. http://www.nbs.rs

35. http://http://www.nbs.rs/internet/cirilica/18/18_1/index.html

36. http://www.nbs.rs

37. http://statline.cbs.nl 